Topics in Applied Macroeconomics 


\section{Topics in Applied Macroeconomics}

EDITED BY

David F. Heathfield

M 
(C) J. D. Byers, E. Greenberg, David F. Heathfield, Kenneth Hilton, George McKenzie, Robert P. Parks,

P. G. Saunders, D. J. Taylor, M. C. Timbrell 1976

Softcover reprint of the hardcover 1st edition 1976 978-0-333-11241-0

All rights reserved. No part of this publication may be reproduced or transmitted, in any form or by any means, without permission

\author{
First published 1976 by \\ THE MACMILLAN PRESS LTD \\ London and Basingstoke \\ Associated companies in New York Dublin \\ Melbourne Johannesburg and Madras
}

ISBN 978-0-333-11249-6 ISBN 978-1-349-86197-2 (eBook)

DOI 10.1007/978-1-349-86197-2

This book is sold subject to the standard conditions of the Net Book Agreement.

The paperback edition of this book is sold subject to the condition that it shall not, by way of trade or otherwise, be lent, resold, hired out, or otherwise circulated without the publisher's prior consent in any form of binding or cover other than that in which it is published and without a similar condition including this condition being imposed on the subsequent purchaser. 


\section{Contents}

List of Contributors

vii

Editor's Preface

1 Econometric Introduction 1

ROBERT P. PARKS

2 Production Functions

DAVID F. HEATHFIELD

3 The Supply of Labour $\quad 69$

J. D. BYERS

4 Fixed Investment

E. GREENBERG

5 Inventory Investment

KENNETH HILTON

6 Imports and Exports

GEORGE McǨENZIE

7 Consumption Functions 164

M. C. TIMBRELL

8 The Demand for Money 186

P. G. SAUNDERS and D. J. TAYLOR

9 Models and Forecasting 208

GEORGE McKENZIE

Index 


\section{List of Contributors}

J. D. BYERs, Lecturer in Economics, University College, Aberystwyth.

E. GREenBerg, Professor of Economics, Washington University, St Louis. DAVID F. HEATHFIELD, Lecturer in Economics, University of Southampton. KENNETh hiLton, Professor of Financial and Managerial Controls, University of Southampton.

G. W. McKENZIE, Lecturer in Economics, University of Southampton. ROBERT P. PARKS, Associate Professor of Economics, Washington University, St Louis.

P. G. SAUNDERS, Lecturer in Economics, University of Sterling.

D. J. TAYLOR, Lecturer in Economics, University of Sterling.

M. C. TIMBRELL, Lecturer in Economics, University of Southampton. 


\section{Editor's Preface}

Students of economics, and observers of the discipline, may be excused for wondering at the profusion of theories directed at explaining economic phenomena. Indeed it has become something of a joke that any two economists will offer at least two different interpretations of the same problem. This springs in part from the normative nature of the social sciences which, being unfamiliar to those trained in the currently dominant physical sciences, is often interpreted, or rather misinterpreted, as woolly thinking. In some ways normative or prescriptive economic statements are of more interest than positive or descriptive statements. It remains true, however, that failure to make this distinction clear has caused, and continues to cause, confusion among economists and to suggest disagreement where none exists. Attempts to make economics more 'scientific', that is to say more positive, have given rise to injunctions for us to 'appeal to the facts'. This book is about appealing to the facts. It is designed to give critical surveys of the empirical work which has been undertaken on those economic relations which are discussed in most introductory or intermediate macroeconomic textbooks. As such it may be viewed as a companion volume to such texts.

Chapter 1 outlines the econometric problems involved in applied work. It is neither rigorous nor exhaustive but is intended to give the reader some understanding of the significance of various estimation procedures, alternative specifications of the structure of the error term and the summary statistics typically attached to empirical results. Chapter 2 deals with production functions and stresses the often implicit assumptions made about the form of the production function in most standard macroeconomic models. The discussion of production functions leads naturally to the discussion of the supply of labour and capital. The supply of labour is dealt with in Chapter 3 which discusses unemployment as a cost of searching for more appropriate employment and attempts to explain participation rates. Chapter 4 outlines various approaches to 
explaining fixed capital formation. Simple accelerator models are developed by the introduction of financial variables, time lags and uncertainty. Investment in inventories is taken up in Chapter 5. The relevance of so small a part of aggregate demand (or supply) is outlined and the various models used to explain both planned and unplanned inventories are critically examined. The difficulties which attend import and export functions are discussed in Chapter 6. A distinction is drawn between the determinants of the long-run pattern of trade and the short-term influences on imports and exports. Chapter 7 on the consumption function deals with the largest element of aggregate demand and compares the alternative theories, first explaining aggregate demand for non-durables, then taking up briefly the demand for consumer durables. Chapter 8 is concerned with the demand for money which is of continued and growing interest in both Keynesian and general-equilibrium models. Finally, Chapter 9 looks at ways in which macroeconomic models are used for policy-making, particularly for forecasting key economic variables. This may be a simple leading indicator or an auto-regressive model or a full economic model. The superiority of this last augers well for the application of economic theory to the problem of controlling economic events.

It will become clear that 'appealing to the facts' is no easy matter, nor is it as objective as the positivists imply. Selection of problems and of theoretical frameworks is normative and even the generation of data involves judgement as to what is the best representation of reality. Typically, in the social sciences, reality is not perceived by the researcher but is represented to him by a set of official statistics. Because of this it is tempting, for example, to assume that what the official statisticians labels as 'unemployment' is precisely what our particular theory calls 'unemployment'. It is also tempting to forget what actual 'raw' data were used in the generation of the published statistics and how much economic theory was implicitly used to derive the latter from the former.

With so many pitfalls it is of little wonder that the empirical work presented here is often inconclusive. It should also be clear that without some quantification of economic theory it is impossible to make any policy recommendations at all; we do not know whether it is better to use monetary or fiscal policy, whether to devalue and if so by how much. It does not seem unreasonable to expect economists to be able to answer such questions. It is hoped that this book will give students some idea of the problems faced by those doing empirical work and hence suggest why it is that 'appealing to the facts' has not yet realised its full potential.

\section{ACKNOWLEDGEMENT}

The original idea for this book and much of the early organisational work for it was due to David Pearce. He relinquished his editorial role on his appointment as Director of the Economic Research Unit at the University of Leicester.

D. F. H. 